\title{
Longer Forms of Amyloid $\beta$ Protein: Implications for the Mechanism of Intramembrane Cleavage by $\gamma$-Secretase
}

\author{
Yue Qi-Takahara, ${ }^{1}$ Maho Morishima-Kawashima, ${ }^{1}$ Yu Tanimura, ${ }^{1}$ Georgia Dolios, ${ }^{2}$ Naoko Hirotani, ${ }^{3}$ Yuko Horikoshi, ${ }^{5}$ \\ Fuyuki Kametani, ${ }^{6}$ Masahiro Maeda, ${ }^{5}$ Takaomi C. Saido, ${ }^{4}$ Rong Wang, ${ }^{2}$ and Yasuo Ihara ${ }^{1}$ \\ ${ }^{1}$ Department of Neuropathology, Faculty of Medicine, University of Tokyo, Tokyo 113-0033, Japan, ${ }^{2}$ Department of Human Genetics, Mount Sinai School of \\ Medicine, New York, New York 10029-6574, ${ }^{3}$ Resources Center and ${ }^{4}$ Laboratory for Proteolytic Neuroscience, Brain Science Institute, RIKEN, Saitama 351- \\ 0198, Japan, ${ }^{5}$ Immuno-Biological Laboratories Company, Ltd., Gunma 375-0005, Japan, and ${ }^{\circ}$ Department of Molecular Neurobiology, Tokyo Institute of \\ Psychiatry, Tokyo 156-8585, Japan
}

$\gamma$-Cleavage of $\beta$-amyloid precursor protein (APP) in the middle of the cell membrane generates amyloid $\beta$ protein (A $\beta$ ), and $\epsilon$-cleavage, $\sim 10$ residues downstream of the $\gamma$-cleavage site, releases the APP intracellular domain (AICD). A significant link between generation of $A \beta$ and AICD and failure to detect AICD41-99 led us to hypothesize that $\epsilon$-cleavage generates longer $A \beta s$, which are then processed to $A \beta 40 / 42$. Using newly developed gel systems and an N-end-specific monoclonal antibody, we have identified the longer $A \beta s$ s $(A \beta 1-43, A \beta 1-45, A \beta 1-46$, and $A \beta 1-48)$ within the cells and in brain tissues. The production of these longer $A \beta s$ as well as $\mathrm{A} \beta 40 / 42$ is presenilin dependent and is suppressed by $\{1 S$-benzyl-4R-[1S-carbamoyl-2-phenylethylcarbamoyl-1S-3-methylbutylcarbamoyl]-2R-hydroxy-5-phenylpentyl $\}$ carbamic acid tert-butyl ester, a transition state analog inhibitor for aspartyl protease. In contrast, $N$-[ $N$-(3,5-difluorophenacetyl)-L-alanyl]-S-phenylglycine t-butyl ester, a potent dipeptide $\gamma$-secretase inhibitor, builds up A $\beta 1-43$ and A $\beta 1-46$ intracellularly, which was also confirmed by mass spectrometry. Notably, suppression of A $\beta 40$ appeared to lead to an increase in $\mathrm{A} \beta 43$, which in turn brings an increase in $\mathrm{A} \beta 46$, in a dose-dependent manner. We therefore propose an $\alpha$-helical model in which longer $\mathrm{A} \beta$ species generated by $\epsilon$-cleavage is cleaved at every three residues in its carboxyl portion.

Key words: amyloid $\beta$-protein; APP; $\gamma$-secretase; intramembrane cleavage; presenilin; Alzheimer's disease

\section{Introduction}

Senile plaques, one of the neuropathological hallmarks of Alzheimer's disease $(\mathrm{AD})$, are composed of a small, $\sim 40$-residue protein called amyloid $\beta$ protein $(\mathrm{A} \beta) . \mathrm{A} \beta$ is produced from $\beta$-amyloid precursor protein (APP), through sequential cleavage by membrane proteases referred to as $\beta$ - and $\gamma$-secretases (Selkoe, 2001). $\beta$-Secretase was identified as a membrane-bound aspartyl protease, $\beta$-site APP-cleaving enzyme (Vassar et al., $1999)$, that generates $\beta \mathrm{CTF}$, an immediate substrate for $\gamma$-secretase, but the nature of $\gamma$-secretase has remained an enigma. Accumulating evidence strongly suggests that $\gamma$-secretase is also an aspartyl protease with its catalytic site(s) sitting within the membrane (for review, see Haass, 2004). Sev-

\footnotetext{
Received April 25, 2004; revised Nov. 26, 2004; accepted Nov. 29, 2004.

This work was supported in part by a grant-in-aid for Scientific Research on Priority Areas (Advanced Brain Science Project) from the Ministry of Education, Culture, Sports, Science and Technology, Japan (Y.I.); a grant-in-aid for Science Research (C) from the Japan Society for the Promotion of Science, Japan (M.M.-K.); and a grant from the National Institutes of Health (R.W.). We thank Dr. E. H. Koo for 7WD10, M146L mtPS1, and V717F mtAPP cells, Dr. S. S. Sisodia for N2a cells overexpressing "Swedish" mtAPP695, Dr. C. Haass for human embryonic kidney cells overexpressing wtAPP695, Dr. T. Iwatsubo for polyclonal anti-PS1 antibody (anti-G1L3), Dr. H. Komano for plasmids for wtAPP695 and $\beta$-amyloid precursor protein carrying endoplasmic reticulum or TGN retention signal, J. Suzuki for L723P mtAPP cells, and Dr. S. Funamoto for constructs of dominant-negative mtPS1 and $\beta$ CTF. We also thank Drs. E. H. Koo and T. Miyasaka for helpful discussions.

Correspondence should be addressed to Dr. Yasuo Ihara, Department of Neuropathology, Faculty of Medicine, University of Tokyo, 7-3-1 Hongo, Bunkyo-ku, Tokyo 113-0033, Japan. E-mail: yihara@m.u-tokyo.ac.jp. DOI:10.1523/JNEUROSCI.1575-04.2005

Copyright $\odot 2005$ Society for Neuroscience $\quad$ 0270-6474/05/250436-10\$15.00/0
}

eral $\mathrm{A} \beta$ species consisting of $36-43$ residues are finally generated and constitutively secreted. Among the secreted species, $A \beta 40$ is the most predominant species, and a longer species, $\mathrm{A} \beta 42$, is a minor one $(<10 \%)$. However, this minor form is indeed initially deposited in the brain and predominates in diffuse and mature plaques (Iwatsubo et al., 1994). This is probably because $A \beta 42$ has a much higher aggregation potential than A $\beta 40$. Most importantly, all of the mutations of presenilin (PS) $1 / 2$ and APP that lead to familial $\mathrm{AD}(\mathrm{FAD})$ cause increased $\mathrm{A} \beta 42$ production (for review, see Selkoe, 2001). Thus, the most important issue is how $\mathrm{A} \beta$, especially $\mathrm{A} \beta 42$, is generated from APP through the action of $\mathrm{PS} 1 / 2$.

APP is cleaved by $\gamma$-secretase, not only in the middle of the transmembrane domain ( $\gamma$-cleavage), but also near the membrane-cytoplasm boundary (referred to as $\epsilon$-cleavage) (Gu et al., 2001; Sastre et al., 2001; Yu et al., 2001; Weidemann et al., 2002). This $\epsilon$-cleavage site is located a few residues inside the membrane from the boundary and is very close to site 3 for cleavage of Notch (for review, see Selkoe and Kopan, 2003). The major product of $\epsilon$-cleavage is an APP intracellular domain (AICD) that begins at Val-50, whereas the minor one is AICD49-99 (Gu et al., 2001; Sastre et al., 2001; Yu et al., 2001; Weidemann et al., 2002).

We have recently found that there is a link between AICD50-99 and A $\beta 40$ production and a link between AICD49-99 and A $\beta 42$ production (Sato et al., 2003). This potential link raises additional questions. Which cleavage, $\gamma$ - or 
$\epsilon$-cleavage, comes first, and how is one related to the other? Because we failed to detect a particular AICD longer than AICD49-99 (Gu et al., 2001), one possibility is that $\beta C$ TF is first cleaved at the $\epsilon$-sites, and the products generated (A $\beta 1-48$ and $1-49)$ undergo $\gamma$-cleavage, generating $A \beta 40 / 42$. Another possibility is that $\gamma$-and $\epsilon$-cleavage occur simultaneously or nearly so along the $\beta \mathrm{CTF}$ molecule, leaving a small, $\sim 10$-residue hydrophobic membrane peptide.

To identify the $\mathrm{A} \beta$ species longer than $\mathrm{A} \beta 1-42$, we have modified an SDS/urea gel system and developed a monoclonal antibody highly specific for the $N$ terminus of $A \beta$. These two tools have now clearly shown the presence of distinct $A \beta$ species longer than $A \beta 1-42$ within the cells and brain. This has important implications for understanding the mechanism of intramembrane cleavage for APP.

\section{Materials and Methods}

Cell culture. Chinese hamster ovary $(\mathrm{CHO})$ cells stably expressing wildtype (wt) APP751 (7WD10 cells) or V717F mutant (mt) APP and 7WD10 cells stably overexpressing M146L mtPS1 were cultured as described previously (Koo and Squazzo, 1994; Podlisny et al., 1995; Xia et al., 1997). Human embryonic kidney 293 (HEK 293) cells stably expressing wtAPP695 and mouse neuroblastoma N2a cells expressing "Swedish" mtAPP695, kindly provided by Drs. C. Haass (Ludwig-Maximilians University, Munich, Germany) and S. S. Sisodia (University of Chicago, Chicago, IL), respectively, were cultured as described previously (Citron et al., 1992; Thinakaran et al., 1996). The 7WD10 cells were transfected stably with wt or various mtPS1/2 cDNAs (Qi et al., 2003).

Generation of cell lines. The pcDNA4/TO vector (Invitrogen, Carlsbad, CA) with SP-DA- $\beta$ CTF1-99 cDNA insert (Lichtenthaler et al., 1999a) was transfected into T-Rex-CHO cells (Invitrogen) using Lipofectamine2000 (Invitrogen), and the stable cell lines were selected using $500 \mu \mathrm{g} / \mathrm{ml}$ Zeocin (Invitrogen). Expression of $\beta$ CTF was induced by the addition of $1 \mu \mathrm{g} / \mathrm{ml}$ tetracycline (Invitrogen) to the culture media. Dominant-negative (DN) mtPS1 (D257A/D385A) (Wolfe et al., 1999) cDNA was generated using the Quick Change Site-Directed Mutagenesis kit (Stratagene, La Jolla, CA). The pIRESneo3 vectors (BD Biosciences, Palo Alto, CA) with wt and DN mtPS1 cDNA inserts were transfected into T-Rex-CHO cells stably expressing $\beta \mathrm{CTF}$, and stable cell lines were selected with $500 \mu \mathrm{g} / \mathrm{ml}$ G418 sulfate. The plasmids of wtAPP695, APP695 bearing a di-lysine endoplasmic reticulum (ER) retention signal (Jackson et al., 1990), and APP695 carrying the trans-Golgi network (TGN) sorting signal of TGN38 (SDYQRL) (Ponnambalam et al., 1994) at its $\mathrm{C}$ terminus were kindly provided by Dr. H. Komano (National Institute for Longevity Sciences, Aichi, Japan) (Sudoh et al., 2000). Each plasmid was transfected to $\mathrm{CHO}$ cells, and stable cell lines were selected with G418.

Treatment with $\gamma$-secretase inhibitors. CHO cells inducibly expressing $\beta C T F$ were incubated with a $\gamma$-secretase inhibitor, either $\{1 S$-benzyl- $4 R$ [1-(1S-carbamoyl-2-phenylethylcarbamoyl)-1S-3-methylbutylcarbamoyl]$2 R$-hydroxy-5-phenylpentyl $\}$ carbamic acid tert-butyl ester (L-685,458) (Calbiochem, San Diego, CA) (Shearman et al., 2000) or $N-[N-(3,5-$ difluorophenacetyl)-1-alanyl]-S-phenylglycine t-butyl ester (DAPT) (Calbiochem) (Dovey et al., 2001), at indicated concentrations for $2 \mathrm{hr}$ and then cultured in the presence of $1 \mu \mathrm{g} / \mathrm{ml}$ tetracycline and each $\gamma$-secretase inhibitor for $4 \mathrm{hr}$ to induce $\beta$ CTF production. The treatment with Compound $\mathrm{E}$ (Calbiochem) (Seiffert et al., 2000) was performed similarly.

Antibodies. Synthetic A $\beta$ peptides (DAEFRHDSGYEVHHQK and DAEFR) were conjugated to thyroglobulin through Cys at the $C$ termini. The former was used for primary immunization with an adjuvant, whereas the latter was used for booster injections. Hybridomas were produced by polyethylene glycol-mediated fusion between immunized splenocytes and X63-Ag8-653 (Kinebuchi et al., 1991), and the clone $82 \mathrm{E} 1$ was selected using peptide-coated immunoplates.

Other monoclonal antibodies against $\mathrm{A} \beta$ that were used were $6 \mathrm{E} 10$ (raised against $\mathrm{A} \beta 1-17), 4 \mathrm{G} 8$ (epitope: $\mathrm{A} \beta 17-24$; Signet Laboratories, Dedham, MA), and BAN50 (raised against A $\beta 1-16$ ) (Suzuki et al., 1994).
The polyclonal antibodies against the cytoplasmic domain of APP were UT421 (Tomita et al., 1998) and C4 (Takio et al., 1989). The polyclonal antibodies against PS1 (anti-G1L3) were described previously (Tomita et al., 1999).

Immunoprecipitation of $A \beta$ from the conditioned media and cell lysates. The conditioned media for $6-8 \mathrm{hr}$ culture were incubated with BAN50 at $4^{\circ} \mathrm{C}$ for $6 \mathrm{hr}$. Harvested cells were lysed with Tris-buffered saline (TBS) (in mM: 50 Tris- $\mathrm{HCl}, \mathrm{pH} 7.6,150 \mathrm{NaCI}, 1$ EGTA, and 1 EDTA) containing $1 \%$ Triton $\mathrm{X}-100$ and various protease inhibitors ( $0.1 \mathrm{~mm}$ diisopropyl fluorophosphate, $0.1 \mathrm{~mm}$ phenylmethylsulfonyl fluoride, $5 \mu \mathrm{g} / \mathrm{ml} \mathrm{N}^{\alpha}$-ptosyl-L-lysine chloromethyl ketone, $1 \mu \mathrm{g} / \mathrm{ml}$ antipain, $1 \mu \mathrm{g} / \mathrm{ml}$ pepstatin, $1 \mu \mathrm{g} / \mathrm{ml}$ leupeptin, $1 \mu \mathrm{g} / \mathrm{ml}$ bestain, $1 \mu \mathrm{g} / \mathrm{ml}$ amerstain, $5 \mathrm{~mm} \mathrm{1,10-}$ phenanthroline monohydrate, and $10 \mathrm{~mm}$ thiorphan). The homogenates were cleared by centrifugation at $540,000 \times g$ for $20 \mathrm{~min}$. The cell lysates were first immunoprecipitated with $\mathrm{C} 4$-bound protein G-Sepharose at $4^{\circ} \mathrm{C}$ for $1 \mathrm{hr}$ to remove full-length APP and $\beta \mathrm{CTF}$, and the resultant supernatants were incubated further with BAN50 at $4^{\circ} \mathrm{C}$ for $6 \mathrm{hr}$. The immune complexes were collected with protein G-Sepharose and eluted with the Laemmli SDS sample buffer. The immunoprecipitated proteins were separated on Tris/Tricine/ $8 \mathrm{~m}$ urea gels, followed by Western blotting with $82 \mathrm{E} 1$.

For each set of the experiments, each supernatant was appropriately diluted to the same protein concentrations, and an equal volume of the supernatant was used for immunoprecipitation.

Fractionation of Tg2576 mouse brain homogenates. The cerebra of 2.5month-old male Tg2576 mice (IBL, Fujioka, Japan) (Hsiao et al., 1996) were homogenized in $5 \mathrm{vol}$ of TBS buffer containing protease inhibitors. The homogenate was centrifuged at $540,000 \times g$ for 20 min to obtain a TBS-soluble fraction. After washing with the same buffer, the resultant pellet was homogenized in $5 \mathrm{vol}$ of TBS buffer containing $1 \%$ Triton $\mathrm{X}-100$ and protease inhibitors, and the homogenate was centrifuged at $540,000 \times g$ for $20 \mathrm{~min}$ to obtain a Triton-soluble fraction. The resulting pellet was suspended in $1 \mathrm{vol}$ of guanidine hydrochloride ( $\mathrm{GuHCI}$ ) by sonication. The suspension was then centrifuged at $265,000 \times g$ for 20 min to obtain a GuHCI-soluble fraction, which was diluted 12-fold. Each fraction was subjected to immunoprecipitation with BAN50, as described above, and then the immunoprecipitates were separated on Tris/ Tricine/8 m urea gels.

Modified Tris/Tricine/8 $\mathrm{m}$ urea gels and Western blotting. To separate $\mathrm{A} \beta 37$ through $\mathrm{A} \beta 49$, the protocol for Tris/Tricine/8 $\mathrm{M}$ urea gel described previously (Klafki et al., 1996) has been modified here. An $11 \%$ T plus $3 \%$ $\mathrm{C}$ separation gel, $\mathrm{pH} 8.45$, containing $8 \mathrm{~m}$ urea was used to separate $\mathrm{A} \beta 37$ through A $\beta 45$ (referred to as gel I). The dimensions of this slab gel were as follows: length of separation gel, $16 \mathrm{~cm}$; length of spacer gel, $0.5 \mathrm{~cm}$; length of stacking gel, $1.5 \mathrm{~cm}$; width, $8.5 \mathrm{~cm}$; thickness, $0.1 \mathrm{~cm}$. To separate $\mathrm{A} \beta 46$ through $\mathrm{A} \beta 49$, a $10 \% \mathrm{~T}$ plus $3 \% \mathrm{C}$ separation gel, $\mathrm{pH} 8.95$, containing $8 \mathrm{~m}$ urea was used (referred to as gel II). The dimensions of this slab gel were as follows: length of separation gel, $20 \mathrm{~cm}$; length of spacer gel, $1.0 \mathrm{~cm}$; length of stacking gel, $1.5 \mathrm{~cm}$; width, $8.5 \mathrm{~cm}$; thickness, $0.1 \mathrm{~cm}$. The compositions of the spacer gel and stacking gel were as described previously (Klafki et al., 1996).

Development of the blots was performed using an ECL system, and intensities of the bands were quantified with a LAS-1000plus luminescent image analyzer (Fuji Film, Tokyo, Japan) (Qi et al., 2003).

Peptide synthesis, purification, and characterization. All A $\beta$ peptides, A $\beta 1-45$ through $A \beta 1-49$, were synthesized using an automated peptide synthesizer (ABI 433A; Applied Biosystems, Foster City, CA). To avoid the formation of deleted derivatives, the amino-terminal extremities without fluorenylmethoxycarbonyl were capped with $0.5 \mathrm{~m}$ acetic anhydride, $0.125 \mathrm{~m} N, N^{\prime}$ diisopropylethylamine, $0.015 \mathrm{~m}$ 1-hydroxybenzotriazole in 1-methyl-2-pyrrolidinone. For the final cleavage from the resin and removal of trifluoroacetic acid (TFA)-labile protecting groups, a mixture of $90 \%$ TFA, $6 \%$ phenol, $4 \%$ thioanisole, $2 \%$ ethanedithiol, and $4 \% \mathrm{H}_{2} \mathrm{O}(\mathrm{v} / \mathrm{v})$ was used for a total volume of $5 \mathrm{ml}$, and the mixture was kept at room temperature for $3 \mathrm{hr}$. Crude peptides were partially purified by size exclusion chromatography on Superdex 75 10/300 GL $(10 \times 300 \mathrm{~mm})$ and Superdex peptide 10/300 GL $(10 \times 300 \mathrm{~mm}$; Amersham Biosciences, Piscataway, NJ $)$ columns, equilibrated with 20\% 2-propanol and $80 \%$ formic acid (v/v) at a flow rate of $0.4 \mathrm{ml} / \mathrm{min}$. 
Sequences of peptides were confirmed by matrix-assisted laser desorption/ionization (MALDI) time-of-flight (TOF) mass spectrometry (Biflex, Bruker, Germany) and by amino acid analysis.

Immunoprecipitation/mass spectrometry assay. $\mathrm{A} \beta$ peptide profiles were analyzed by immunoprecipitation/mass spectrometry (Wang et al., 1996). Aliquots of conditioned media containing 1\% FCS and lysates from cells inducibly expressing $\beta$ CTF that were treated with and without DAPT were immunoprecipitated by monoclonal antibodies $4 \mathrm{G} 8 / 6 \mathrm{E} 10$ and protein $\mathrm{G} / \mathrm{A}$ agarose. $\beta \mathrm{CTF}$ in the cell lysates was preabsorbed with C4-bound protein G-Sepharose. The molecular masses of immunoprecipitated $\mathrm{A} \beta$ species were measured using a Voyager-DE STR MALDI TOF mass spectrometer (Applied Biosystems). Peptide samples were prepared by the thin-layer method using $\alpha$-cyano-4-hydroxycinnamic acid as matrix. Each spectrum was collected from 1000 laser irradiations. Mass spectra were calibrated using bovine insulin as the internal mass calibrant. Peaks corresponding to $A \beta$ peptides were identified using the measured molecular masses searching against $\mathrm{A} \beta$ peptide sequence with a mass error tolerance of $200 \mathrm{ppm}$.

Other methods. Protein concentrations were determined in the presence of $1 \%$ SDS using the bicinchoninic acid protein assay reagent (Pierce, Rockford, IL).

\section{Results}

Modified Tris/Tricine/8 $\mathrm{M}$ urea gels and a monoclonal antibody, 82E1

Because we were unable to detect longer AICD forms, including AICD41-99 and AICD43-99, in the cell lysates, we postulated that there might be a particular $\mathrm{A} \beta$ species longer than $\mathrm{A} \beta 40 / 42$. Thus, we modified the Tris/Tricine/ $8 \mathrm{M}$ urea gel system (Klafki et al., 1996) and developed two gel systems to separate the $A \beta$ species, $A \beta 1-37$ through $A \beta 1-45$ and $A \beta 1-46$ through $A \beta 1-49$.

Synthetic $A \beta 1-37$ through $A \beta 1-45$ peptides were well separated by modifying the length of the gel and reducing the concentrations of acrylamide (see Materials and Methods). Because this gel system (termed gel I) cannot separate $\mathrm{A} \beta 1-46$ through $\mathrm{A} \beta 1-$ 49 , which are stuck at the gel front (Fig. $1 A$ ), we developed a second gel system (termed gel II). Gel II has three modifications: extended gel length, reduced acrylamide concentrations, and slight alkalization of the separation gel (see Materials and Methods). In contrast to gel I, gel II is unable to separate A $\beta$ species shorter than $\mathrm{A} \beta 1-45$, which are now stuck at the upper region of the gel, but can separate well $A \beta 1-45$ through $A \beta 1-49$ (Fig. $1 B$ ). The striking characteristic of these gel systems is that longer $A \beta s$ migrate faster than shorter ones.

Because our primary concern was the $\mathrm{C}$-terminal processing of $\mathrm{A} \beta$, we sought to focus on $\mathrm{A} \beta 1-\mathrm{Xs}, \mathrm{A} \beta$ peptides that start from Asp-1. Otherwise, results must have been confounded by the presence of numerous $\mathrm{N}$-terminally truncated $\mathrm{A} \beta \mathrm{s}$ that extend similarly to various $\mathrm{C}$ termini (Haass et al., 1994; Wang et al., 1996). If we could collect only $A \beta 1-X s$, identification of longer $\mathrm{A} \beta$ s would become possible by comparing their electrophoretic mobilities with those of authentic synthetic $A \beta 1-X s$. We thus developed a new monoclonal antibody, 82E1. Whereas 6E10 labeled $\mathrm{A} \beta 1-40, \mathrm{~A} \beta 2-40$, and $\mathrm{A} \beta 3-40$ to the same extent, $82 \mathrm{E} 1$ labeled only $\mathrm{A} \beta 1-40$, but never those truncated $\mathrm{A} \beta$ s (Fig. $1 C$ ). The full-length APP and its several derivatives, $\beta$ CTF and its $\mathrm{N}$-terminally extended forms, were strongly labeled with $6 \mathrm{E} 10$ but never with $82 \mathrm{E} 1$, except for $\beta \mathrm{CTF}$ (Fig. $1 D$ ). Thus, $82 \mathrm{E} 1$ is highly specific for the $\mathrm{N}$ terminus of $\mathrm{A} \beta$ or $\beta \mathrm{CTF}$ and is virtually end specific. Furthermore, 82E1 showed similar affinities for $\mathrm{A} \beta 1-40, \mathrm{~A} \beta 1-42$, and $\mathrm{A} \beta 1-43$ (data not shown), suggesting that this would also be the case with other shorter and longer $A \beta s$ that start from Asp-1. Thus, the intensity of the 82E1 immunoreactivity should reflect the concentrations of various $A \beta 1-X s$ in the cell lysates. Hereafter, $\mathrm{A} \beta \mathrm{X}$ represents $\mathrm{A} \beta 1-\mathrm{X}$.
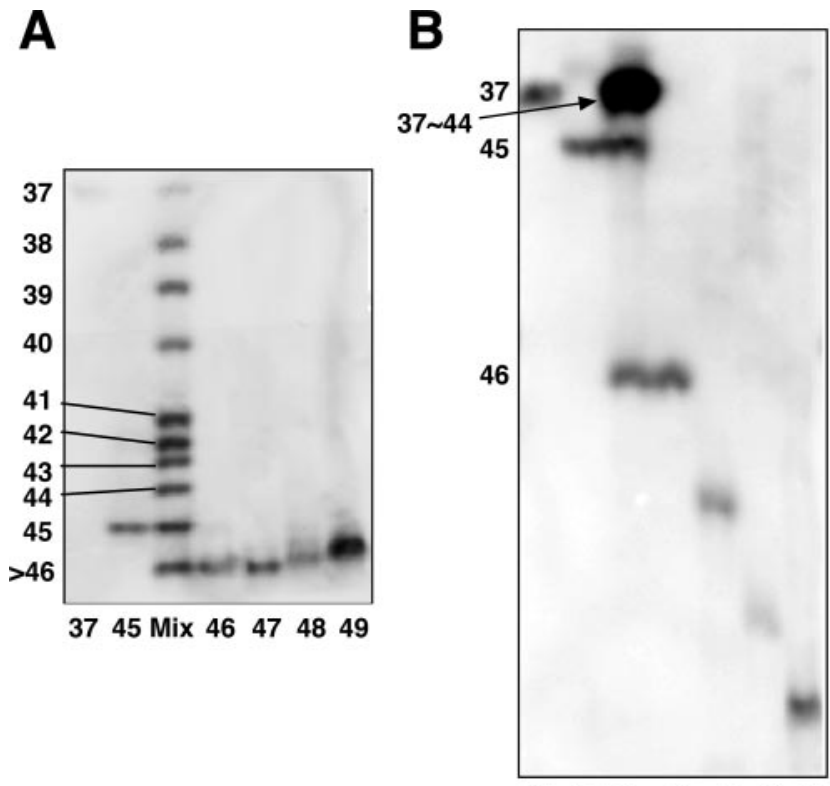

3745 Mix $46 \quad 4748 \quad 49$

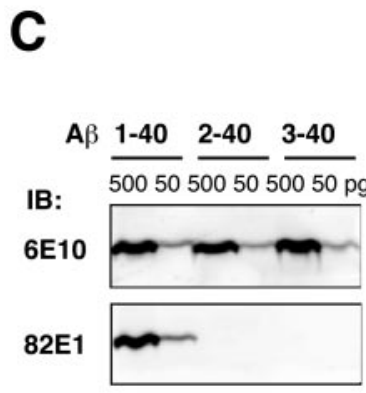

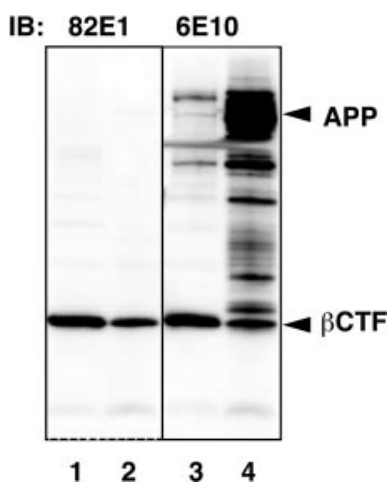

Figure 1. Modified Tris/Tricine/ $8 \mathrm{~m}$ urea gels and specificity of $82 \mathrm{E} 1 . A, B$, Synthetic $A \beta 1-37$ through $A \beta 1-49$ were separated using gel I $(A)$ and gel II $(B)$. In gel I $(A), A \beta 1-37$ through $A \beta 1-45$ are clearly separated, whereas $A \beta 1-46$ through $A \beta 1-49$ are stuck at the gel front. In gel II $(B), A \beta 1-45$ through $A \beta 1-49$ are well separated, whereas $A \beta 1-37$ through $A \beta 1-44$ are stuck at the upper region of the gel. $C$, Synthetic $A \beta 1-40, A \beta 2-40$, and $A \beta 3-40$ ( 500 and $50 \mathrm{pg}$ of each) were subjected to Western blotting using $6 \mathrm{E} 10$ (top) or $82 \mathrm{E} 1$ (bottom). Whereas 6 E10 labeled all of these $A \beta$ s to similar extents, $82 E 1$ recognized only $A \beta 1-40 . D$, The cell lysates from CHO cells overexpressing $\beta$ CTF (lanes 1,3) or APP (lanes 2, 4) were subjected to Western blotting with $82 \mathrm{E} 1$ (left) or 6E10 (right). 82E1 specifically labeled $\beta$ CTF but not fulllength APP or several APP-derived products that are strongly labeled with 6E10.

\section{Longer A $\beta$ s in various cell lysates and APP-transgenic} mouse brain

We first sought to detect longer $\mathrm{A} \beta$ s in the cultured media and in the cell lysates of 7WD10 cells, CHO cells overexpressing wtAPP. The $\mathrm{A} \beta$ species in the culture media and lysates were immunoprecipitated with BAN50 and subjected to electrophoresis on the above two gels, followed by Western blotting with 82E1.

Various $\mathrm{A} \beta$ species, including $\mathrm{A} \beta 37, \mathrm{~A} \beta 38, \mathrm{~A} \beta 39, \mathrm{~A} \beta 40$, and $A \beta 42$, were present in the conditioned media, an observation consistent with previous reports (Wang et al., 1996; Clarke et al., 1998; Beher et al., 2002) (Fig. 2 A). A $\beta 43$ was virtually undetectable in the media using this protocol. In contrast, $\mathrm{A} \beta$ species longer than $A \beta 42$, including $A \beta 43, A \beta 45, A \beta 46$, and $A \beta 48$, were reproducibly detectable in the cell lysates (Fig. $2 A$ ). It was difficult to see $\mathrm{A} \beta 37$ (and sometimes $\mathrm{A} \beta 38$ ) clearly in the lysate, because of superimposition with $\beta \mathrm{CTF}$ on gel I (Fig. $2 A$ ). In the $7 \mathrm{WD} 10$ cells secreting predominantly $\mathrm{A} \beta 40$, three species $(\mathrm{A} \beta 40$, 
A

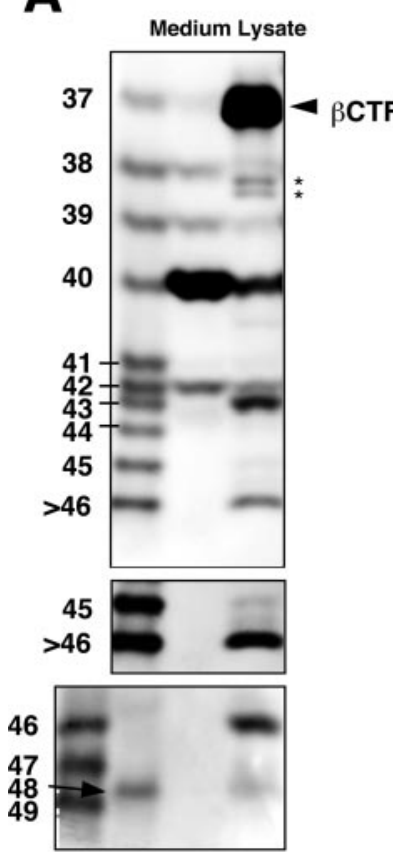

B

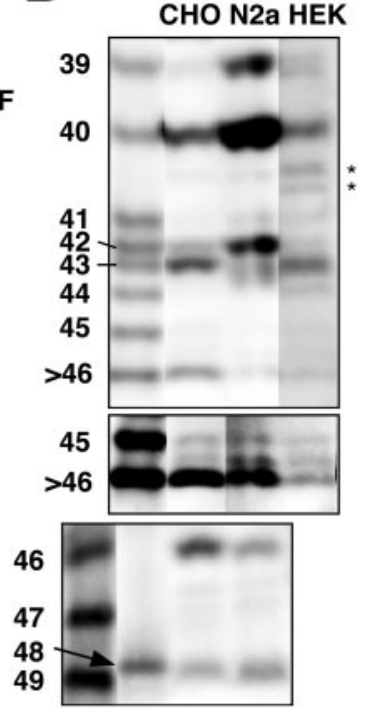

C

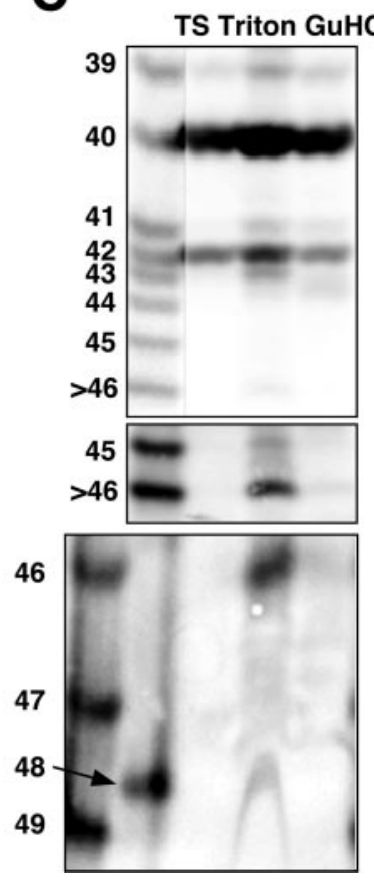

Figure 2. Longer A $\beta$ s in the various cell lysates and the APP-transgenic mouse brain. A, BAN50 immunoprecipitates from the conditioned medium (Medium) and Triton-soluble fraction (Lysate) of 7WD10 cells were separated on gel I (top and middle) and gel II (bottom) and subjected to Western blotting with 82E1. The middle panel represents an overexposed blot (the same as above). $A \beta$ species longer than $A \beta 42$ are undetectable in the conditioned medium but are detectable in the cell lysate. $B, B A N 50$ immunoprecipitates of Triton-soluble fractions from $\mathrm{CHO}, \mathrm{N2a}$, and HEK cell lines stably expressing APP were separated on gel I (top and middle) and gel II (bottom) and subjected to Western blotting with 82E1. The middle panel represents an overexposed blot. Although the relative levels of $A \beta$ species differ, the same longer $A \beta$ species as found in $\mathrm{CHO}$ cells are detectable in the N2a and HEK cell lines. In N2a cell line, a band just above $A \beta 42$ presumably represents $A \beta 41$. The origins of an extra band below $A \beta 43$ in the N2a lane and a band located between $A \beta 45$ and $A \beta 46$ seen in all three lanes are unknown. $C, A \beta 43, A \beta 45, A \beta 46$, and $A \beta 48$ are found exclusively in the Triton-soluble fraction of (plaque-free) brain homogenates from 2.5-month-old APPtransgenic mice (Tg2576). Immunoprecipitates from TBS- (TS), Triton-, and GuHCl-soluble fractions of Tg2576 mouse brain homogenates were separated on gelI (top and middle) and gel II ((TS) bottom) and subjected to Western blotting with 82E1. The middle panel represents an overexposed blot. A weakly immunoreactive band above $A \beta 42$ in the Triton lane presumably represents $A \beta 41$. The asterisks in $A$ and $B$ are presumably $C$-terminally truncated $\beta C T F s$. When different gel conditions are used, these bands exhibit the various mobilities relative to those of synthetic $A \beta$ s, which contrasts with the observation that longer $A \beta s$ identified here always comigrate with corresponding synthetic $A \beta s$.

$\mathrm{A} \beta 43$, and $\mathrm{A} \beta 46)$ were the major ones in the lysates, which contrasts with trace amounts of $\mathrm{A} \beta 42, \mathrm{~A} \beta 45$, and $\mathrm{A} \beta 48$ (Fig. $2 A$ ). We were consistently unable to detect $A \beta 49$, the longest $A \beta$ that we postulated exists (Fig. 2A).

To exclude the possibility that these longer $A \beta$ s are inherent to $\mathrm{CHO}$ cells, we searched for longer A $\beta$ s in N2a cells stably expressing Swedish mtAPP and HEK 293 cells stably expressing wtAPP. Those longer $\mathrm{A} \beta \mathrm{s}$, including $\mathrm{A} \beta 43, \mathrm{~A} \beta 45, \mathrm{~A} \beta 46$, and $\mathrm{A} \beta 48$, were detectable in N2a and HEK 293 cells as in CHO cells, although the proportions and levels of each longer $\mathrm{A} \beta$ differed among these three cell lines (Fig. $2 B$ ). The levels of longer $A \beta$ s relative to those of $\mathrm{A} \beta 40 / 42$ were slightly higher in $\mathrm{CHO}$ and HEK cells (Fig. 2 B). In contrast, $N 2$ a cells showed higher levels of $A \beta 39 / 40 / 42$ and relatively lower levels of longer $A \beta$ s (Fig. $2 B$ ). One more characteristic of $\mathrm{N} 2 \mathrm{a}$ cells may be the presence of $\mathrm{A} \beta 41$ (Fig. $2 \mathrm{~B}$ ). Most interestingly, there were no differences in the levels of secreted $A \beta$ species among those cell lines (data not shown). These results clearly show that various $A \beta$ species longer than $A \beta 42$ exist in the lysates of various cell lines but are undetectable in their culture media.

We next asked whether those longer $A \beta$ s exist in the brain of the APP-transgenic mouse strain Tg2576 (Hsiao et al., 1996). The

homogenates of brains from 2.5-monthold Tg2576 mice were fractionated into three fractions (TBS-soluble, Tritonsoluble, and GuHCl-soluble fractions), each of which was subjected to immunoprecipitation and Western blotting. Longer $A \beta$ s, including $A \beta 43, A \beta 45, A \beta 46$, and $A \beta 48$, were identified mostly in the Triton-soluble fraction but not in the TBSsoluble fraction of the homogenates (Fig. $2 C)$, strongly suggesting that these longer $\mathrm{A} \beta \mathrm{s}$ are associated with the membrane in the brain. Interestingly, the Triton-soluble fraction contained $\mathrm{A} \beta 41$, which was detected in N2a cells (Fig. $2 B, C$ ). The same longer $A \beta$ species were also detected in the brains of 1.3-month-old PDAPP mice (Games et al., 1995) (data not shown).

\section{Generation of longer $A \beta$ s depends on PS}

Because the generation of $A \beta 40 / 42$ requires PSs (De Strooper et al., 1998), we next investigated whether the generation of longer $A \beta s$ also depends on PSs. To readily detect longer $\mathrm{A} \beta \mathrm{s}$, a stable $\mathrm{CHO}$ cell line that inducibly expresses $\beta$ CTF using the T-Rex system was generated, and the vectors carrying wtPS1 or DN (D257A/D385A) mtPS1 construct were stably transfected into this $\beta$ CTF cell line. After induction of $\beta C T F$ for $4 \mathrm{hr}$, the wtPS1 and DN mtPS1 cells were examined for the levels of AICD and $\mathrm{A} \beta$.

The expression of DN mtPS1 caused a marked reduction in the levels of both AICD and intracellular A $\beta$ s (Fig. $3 B$ ). Note that trace amounts of AICD and $A \beta$ were still generated in DN mtPS1 cells. This is probably because endogenous PS1/2 were not completely replaced by the biologically inactive mtPS1 (Fig. $3 A$ ) and maintained some $\gamma$-cleavage activities. Gel I clearly showed that DN mtPS1 greatly reduced the levels not only of $A \beta 40 / 42$ but also of longer $A \beta$ s, including $A \beta 43, A \beta 45$, and $A \beta 46$ (Fig. $3 C$ ). Several 82E1-immunoreactive bands that do not correspond to any of the authentic $\mathrm{A} \beta \mathrm{X}$ s were discernible in the lysates of $\beta \mathrm{CTF}$ cells (Fig. 3 B, C). They are, presumably, C-terminally truncated products derived from $\beta$ CTF. Their levels apparently increased by suppression of $\gamma$-cleavage, presumably because steady-state levels of $\beta$ CTF become elevated and it is more susceptible to proteolysis (Fig. $3 B, C$ ).

In addition, the cells that inducibly express $\beta$ CTF were treated with a $\gamma$-secretase inhibitor, L-685,458 (Shearman et al., 2000; Li et al., 2000). The cells were first treated with various concentrations of L-685,458 for $2 \mathrm{hr}$, and then $\beta$ CTF production was induced for $4 \mathrm{hr}$ in the presence of the inhibitor. The levels of AICD and intracellular and secreted $\mathrm{A} \beta$ were suppressed in dosedependent manners (Fig. 4A). Gels I and II clearly showed that the intracellular levels of $A \beta 40 / 42$ and longer $A \beta$ s were also uniformly suppressed in dose-dependent manners (Fig. $4 B, C$ ). Thus, the generation of longer $A \beta$ s, including $A \beta 43, A \beta 45$, $\mathrm{A} \beta 46$, and $\mathrm{A} \beta 48$, is mediated by $\gamma$-secretase. 


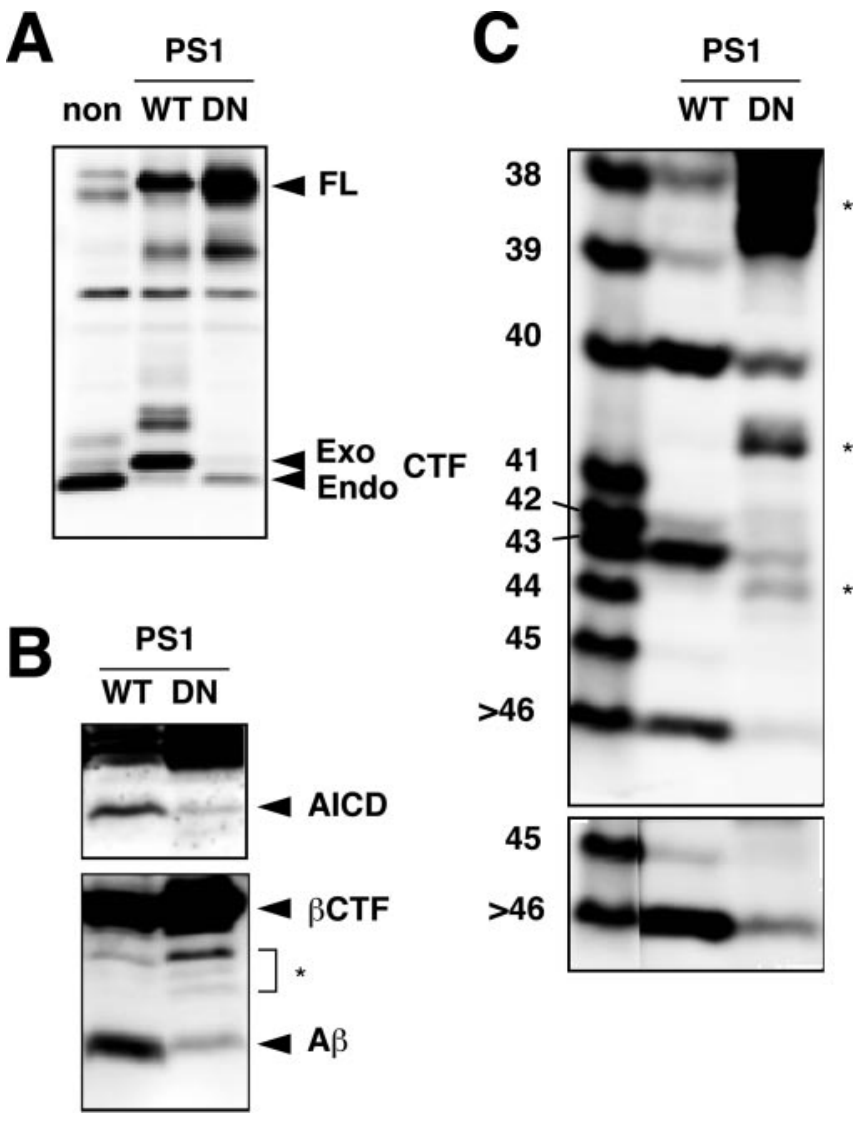

Figure 3. A DN mutant of PS1 greatly reduced intracellular levels of longer $A \beta s . A$, $C H O$ cells that inducibly express $\beta$ CTF were stably transfected with CDNAs encoding wt (WT) or DN (D257A/D385A) mtPS1. Exogenous human wt or mtPS1 displaced endogenous PS1 to a large extent. Lysates were prepared from a nontransfectant (non) and the two transfectants, and equal amounts of protein were subjected to Western blotting with anti-G1L3. Full-length PS1 (FL) and endogenous (Endo) and exogenous (Exo) CTFs are indicated by arrowheads. B, The DN $\mathrm{mtPS} 1$ caused a remarkable reduction in the levels of AICD and $A \beta$ in the lysate. After induction of $\beta C T F$ for $4 \mathrm{hr}$, the lysates were prepared from these two transfectants, and equal amounts of protein were subjected to Western blotting using UT421 (top) or $82 \mathrm{E} 1$ (bottom). C, The levels of longer $A \beta$ s were also greatly suppressed by the expression of DN mtPS1. The immunoprecipitates from the Triton-soluble fraction of the two stable transfectants were separated on gell and then subjected to Western blotting with 82E1. The bottom panel represents an overexposed blot. A couple of bands indicated by asterisks in $B$ and $C$ presumably represent C-terminally truncated $\beta$ CTFs. The inhibition of $\gamma$-secretase caused an increase of those bands.

\section{Longer $\mathrm{A} \beta$ s are produced at the same subcellular location as $\mathrm{A} \boldsymbol{\beta} 40 / 42$}

To investigate where the longer $\mathrm{A} \beta$ s are produced, stable $\mathrm{CHO}$ cells overexpressing wtAPP, APP bearing a di-lysine motif (ER retention signal) (APP/ER) (Jackson et al., 1990), or APP carrying the sorting signal SDYQRL of TGN38 (APP/TGN) (Ponnambalam et al., 1994) were established and examined for the intracellular levels of various $\mathrm{A} \beta$ species.

In APP/ER cells, the level of AICD was similar to that in nontransfected CHO cells, whereas in wtAPP and APP/TGN cells, the level of AICD was increased (data not shown). No intracellular A $\beta$ species were detectable in the APP/ER cell lysates, whereas in APP/ TGN cells the intracellular levels of $A \beta$ s were increased compared with those in wtAPP cells (Fig. 5). Moreover, the A $\beta$ species found in APP/TGN cells were the same as detected in the lysates of wtAPP cells and other cell lines (Fig. $2 B, 5 B$ ): $A \beta 40, A \beta 43$, and $A \beta 46$ were abundant, whereas $A \beta 42, A \beta 45$, and $A \beta 48$ were minor species. These data suggest that both $A \beta 40 / 42$ and longer $A \beta$ species are produced mainly in the TGN but not in the ER.

\section{MtPS1/2 and mtAPP affect the intracellular levels of} longer $A \beta$ s

We next asked whether and how the mutations of PS1/2 affect the intracellular levels of longer A $\beta$ s. WtPS1 and wtPS2 had varying effects on the levels of longer A $\beta$ s. Overproduction of wtPS2 caused increases in the intracellular levels of $A \beta 40 / 42$ and concomitant decreases in the levels of $\mathrm{A} \beta 43, \mathrm{~A} \beta 45$, and $\mathrm{A} \beta 46$ compared with 7WD10 cells (Fig. $6 A$ ). In contrast, overproduction of wtPS1 caused small increases in the levels of $A \beta 43$ and $A \beta 46$ but did not alter the levels of $A \beta 40 / 42$ (Fig. $6 B$ ).

In contrast, $\mathrm{mtPS} 2 \mathrm{~s}$ caused distinct changes in the intracellular levels of $\mathrm{A} \beta 40 / 42$ and longer $\mathrm{A} \beta \mathrm{s}$. N141I and T122P mtPS2s showed similar alterations in the intracellular $A \beta$ levels: a marked increase in $\mathrm{A} \beta 42$ and a concomitant decrease in $\mathrm{A} \beta 40$ (Fig. $6 A$ ) (Qi et al., 2003). Both also caused an increase in the level of $A \beta 45$ and decreases in the levels of $A \beta 43$ and $A \beta 46$ (Fig. 6A). N135D $\mathrm{mtPS} 1$ is homologous to N141I mtPS2, and both showed similar alterations in the intracellular levels of $A \beta s$ (Fig. $6 B$ ).

M233T mtPS1 caused a remarkable increase in the level of $A \beta 48$ and substantial increases in the levels of $A \beta 39$ and $A \beta 42$ (Fig. $6 B$ ). At the same time, it accompanied decreases in the levels of $A \beta 40, A \beta 43$, and $A \beta 46$ (Fig. $6 B$ ). Other mtPS1s caused various changes in the levels of longer $A \beta s$, although they invariably resulted in a significant increase in the levels of $A \beta 42$ (Fig. 6C) (Qi et al., 2003). M146L and G384A mtPS1 caused decreases in the levels of $A \beta 43$ and $A \beta 46$, whereas H163R mtPS1 did not alter their levels compared with wtPS1 (Fig. 6C). M146L mtPS1 caused an increase in $\mathrm{A} \beta 48$, whereas G384A and H163R mtPS1 caused decreases in $\mathrm{A} \beta 48$ (Fig. $6 \mathrm{C}$ ). None of these three mtPS1s caused an increase in the levels of $A \beta 45$ (Fig. $6 C$ ).

Therefore, we conclude that the FAD-associated PS1/2 mutations have distinct effects on the levels of each longer $\mathrm{A} \beta$ and bring about increased intracellular levels of $\mathrm{A} \beta 42$. This indicates that numerous, diverse effects of $\mathrm{mtPS} 1 / 2$ on the levels of each longer $\mathrm{A} \beta$ could cause finally increased levels of intracellular $\mathrm{A} \beta 42$.

FAD-associated mtAPPs also enhance $\mathrm{A} \beta 42$ production (for review, see Selkoe, 2001). We thus examined the intracellular A $\beta$ species in CHO cells overexpressing wtAPP (7WD10 cells), V717F mtAPP, or L723P mtAPP. The levels of APP and $\beta$ CTF were similar among these three transfectant lines (Fig. $7 A$ ). V717F and L723P mtAPP caused increases in the intracellular levels of $A \beta 42$ and slight decreases in the levels of $A \beta 40$ compared with 7WD10 cells (Fig. 7B). L723P mtAPP caused a discernible increase in the level of $A \beta 45$, whereas V717F mtAPP did not alter the level of $A \beta 45$ compared with 7WD10 cells, but both caused subtle decreases in the levels of $A \beta 48$ (Fig. $7 B, C$ ). In addition, the levels of $A \beta 43$ and $A \beta 46$ in V717F mtAPP cells were increased, whereas their levels were decreased in L723P mtAPP cells (Fig. $7 B, C)$. These results indicate that these two mtAPPs alter the intracellular levels not only of $A \beta 42$ but also of longer $A \beta$ s.

\section{DAPT causes differential accumulations of longer A $\beta$ s within} the cell

A dipeptide inhibitor, DAPT very efficiently inhibits the secretion of A $\beta 40 / 42$ (Dovey et al., 2001; Sastre et al., 2001) and is regarded as a potent $\gamma$-secretase inhibitor. As expected, DAPT caused a reduction in the levels of AICD and secreted $A \beta$ in a dosedependent manner (Fig. 8A) (Dovey et al., 2001; Sastre et al., 2001). It also reduced the levels of total intracellular $A \beta$ (Fig. $8 A$ ). However, after careful inspection of the blots, it becomes evident that, with increasing concentrations of DAPT, the proportion of intracellular $\mathrm{A} \beta$ with fast mobility decreased and that of the $\mathrm{A} \beta$ with slow mobility even slightly increased on a Tris/Tricine gel 


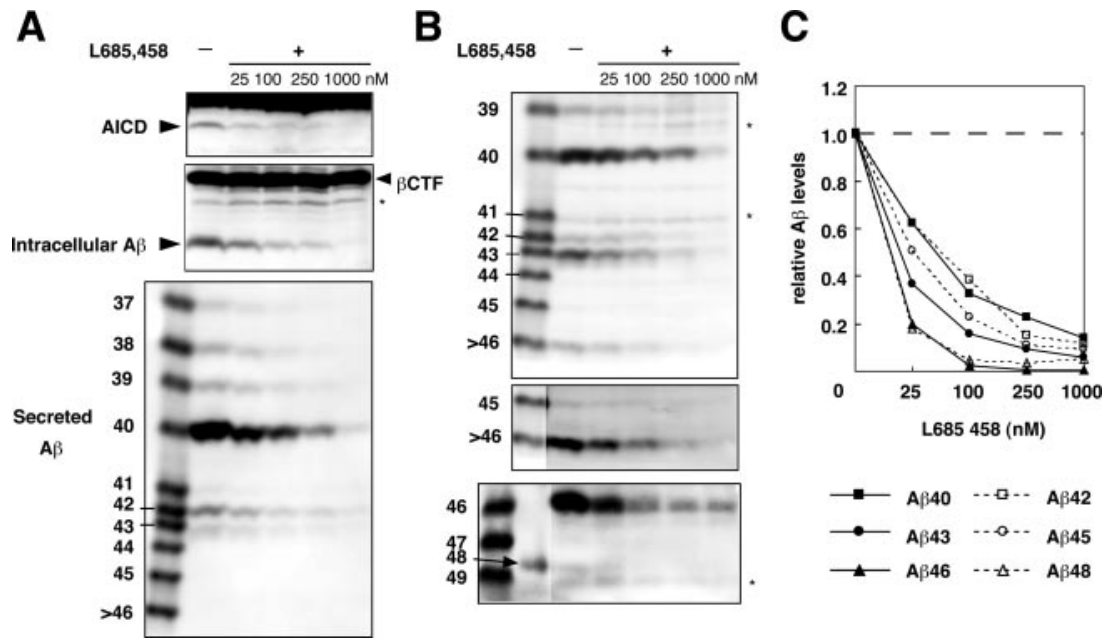

Figure 4. $L-685,458$ suppressed the levels of longer $A \beta s$. $A$, The cells that inducibly express $\beta C T F$ were first treated with indicated concentrations of L-685,458 for $2 \mathrm{hr}$, and $\beta$ CTF was induced for $4 \mathrm{hr}$ in the presence of L-685,458. Equal amounts of protein from whole-cell lysates were subjected to Western blotting with UT421 (top) and 82 E1 (middle). The BAN50 immunoprecipitates from the medium were separated on gel I and subjected to Western blotting with $82 E 1$ (bottom). B, Triton-soluble fractions of those treated cells were immunoprecipitated with BAN50, and the collected proteins were separated on gelI (top and middle) and gel II (bottom) and subjected to Western blotting with 82E1. The middle panel represents an overexposed blot. The asterisks in $A$ and $B$ indicate C-terminally truncated $\beta$ CTFs. C, The amounts of intracellular $A \beta$ were quantified using LAS-1000plus luminescent image analyzer. The levels of each $A \beta$ species were normalized to those in the nontreated cells. The data shown are the means of the values from three (for $A \beta 40, A \beta 42, A \beta 43$, and $A \beta 45$ ) or two (for $A \beta 46$ and $A \beta 48$ ) independent experiments.

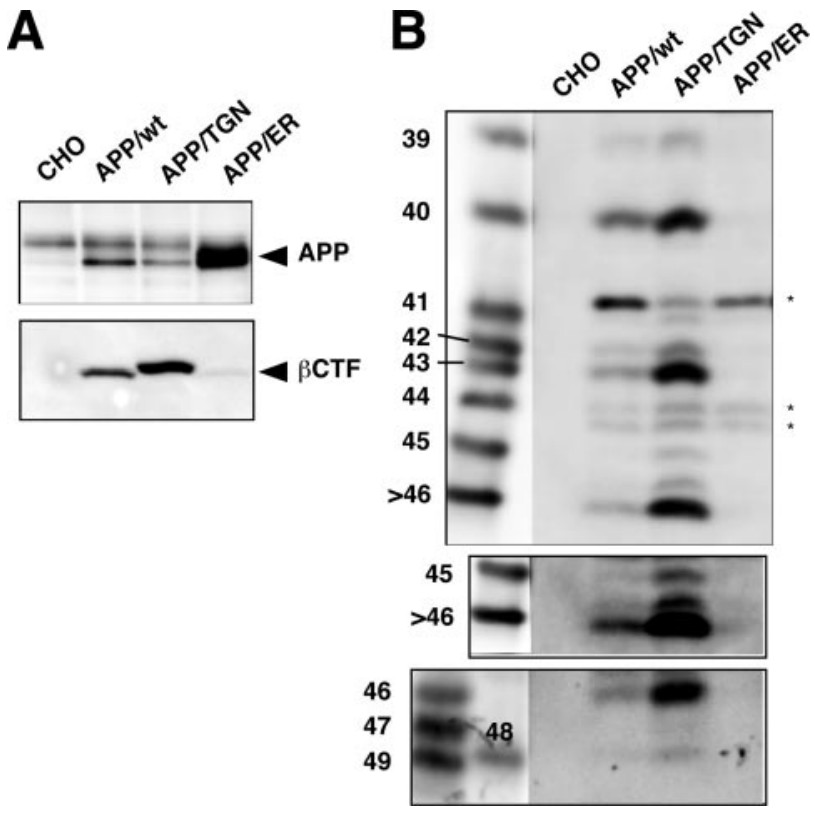

Figure 5. Longer $A \beta$ forms are produced at the same location as $A \beta 40 / 42 . A$, Stable cell lines overexpressing wtAPP (APP/wt), APP carrying a TGN38 sorting signal (APP/TGN), or an ER retention signal (APP/ER) were generated. The cell lysates with the same amounts of protein were subjected to Western blotting with UT421 for full-length APP (top) or with 82E1 for $\beta$ CTF (bottom). $B$, Triton-soluble fractions from these cell lines with the same amounts of protein were immunoprecipitated with BAN50. The immunoprecipitates were separated on gel I (top and middle) and gel II (bottom) and subjected to Western blotting with 82E1. The middle panel represents an overexposed blot. The longer $A \beta$ forms, including $A \beta 43, A \beta 45, A \beta 46$, and $A \beta 48$, were clearly visible in the APP/TGN cells. A couple of bands indicated by asterisks in $B$ are presumably C-terminally truncated $\beta$ CTFs.

without urea (Fig. $8 A$ ). Moreover, the intracellular $\mathrm{A} \beta$ was more resistant to DAPT than the secreted $\mathrm{A} \beta$. The intracellular $\mathrm{A} \beta$ was clearly visible even at $1000 \mathrm{~nm}$ DAPT, whereas at the same concentration, the secreted $\mathrm{A} \beta$ was barely discernible (Fig. $8 A$ ). Re- garding AICD, only small amounts were detected at 1000 nm DAPT (Fig. 8A), and thus its counterpart would be converted to intracellular $\mathrm{A} \beta$, although the decay response of AICD should be best reflected by the amounts of the secreted $\mathrm{A} \beta$ which accounts for the majority of produced $A \beta$. This contrast with the effects of L-685,458, in which the intracellular $\mathrm{A} \beta$, the secreted $\mathrm{A} \beta$, and AICD showed similar decay responses (Fig. 4A).

The new gel systems demonstrated that the intracellular levels of $A \beta 40$ and $A \beta 42$ were increasingly suppressed by DAPT in dose-dependent manners: 5 nM DAPT had a negligible effect on their levels, but $50 \mathrm{~nm}$ DAPT substantially suppressed their levels (Fig. $8 B, C$ ). The levels of $\mathrm{A} \beta 45$ appeared to be less affected by the DAPT treatment than those of $\mathrm{A} \beta 42$ (Fig. $8 B, C$ ). Surprisingly, $A \beta 43$ and $A \beta 46$ accumulated in the cells and showed distinct patterns. The levels of $\mathrm{A} \beta 43$ increased at $5 \mathrm{nM}$ DAPT, reached a maximum at $50 \mathrm{nM}$, and gradually declined. The levels of $\mathrm{A} \beta 46$ gradually increased to a maximum at $250 \mathrm{nM}$, followed by a slight decline at $1000 \mathrm{~nm}$ (Fig. $8 B, C)$. These increases in the intracellular $A \beta 43$ and $A \beta 46$ levels after DAPT treatment were confirmed by immunoprecipitation/ mass spectrometry analysis (Fig. 8D). The intracellular accumulations of longer $A \beta$ s and "up and down" responses are a striking characteristic of the DAPT treatment. Notably, decreasing levels of $A \beta 40$ are followed by an increase in the levels of $A \beta 43$, and decreasing levels of this, in turn, are followed by increases in the levels of $\mathrm{A} \beta 46$ (Fig. $8 \mathrm{~B}, \mathrm{C}$ ). Thus, it appears that suppression of $\mathrm{A} \beta 40$ leads to an increase in $\mathrm{A} \beta 43$, which in turn brings an increase in $A \beta 46$. These data suggest that $A \beta 40$ is produced successively from $A \beta 46$ through $A \beta 43$ or, alternatively, that the substrate is competitive for the $A \beta 40$-, $A \beta 43$-, or $A \beta 46$-cleavage site of $\gamma$-secretase, and DAPT is the most potent for A $\beta 40$-cleavage.

Compound E (Seiffert et al., 2000), another nontransitionstate analog inhibitor for $\gamma$-secretase, provided very similar, but not identical, results. When the cells were treated with increasing concentrations of Compound $E$, the levels of $A \beta 40$ and $A \beta 43$ showed similar decay profiles, which accompanied a gradual increase and a subsequent decrease in the levels of $A \beta 46$ (data not shown).

\section{Discussion}

\section{Multiple cleavage sites exist between the $\gamma$ - and} $\epsilon$-cleavage sites

The $\mathrm{A} \beta$ species that were detected in the cells and brain are not necessarily all of the possible $A \beta$ species of $A \beta 43$ through $A \beta 49$ differing from each other by one residue. For example, we did not consistently detect $\mathrm{A} \beta 41, \mathrm{~A} \beta 44$, and $\mathrm{A} \beta 47$, although it is likely that a trace amount of $A \beta 41$ exists in the N2a cell line and the Tg2576 brain. Despite intensive efforts, we were unable to detect $\mathrm{A} \beta 49$ in the cell lysates; this is a counterpart of the major AICD50-99 that would have been generated by $\epsilon$-cleavage. Thus, the major intracellular $A \beta$ species were $A \beta 40, A \beta 43$, and $A \beta 46$, whereas $A \beta 42, A \beta 45$, and $A \beta 48$ were minor ones in the $\mathrm{CHO}$ cells overexpressing wtAPP. In contrast, in mtPS2 cell lines, the levels of $A \beta 42$ and $A \beta 45$ were increased, whereas those of $A \beta 40$, 
$\mathrm{A} \beta 43$, and $\mathrm{A} \beta 46$ were decreased (Fig. $6 A$ ). In mtPS1 cell lines, when the levels of $A \beta 40$ were suppressed, those of $A \beta 43$ and A $\beta 46$ were also decreased (Fig. $6 B$ ) compared with 7WD10 or wtPS1 cells. In addition, according to our preliminary experiments, CHO cells expressing V721K APP produced mainly AICD47-99 and A $\beta 40$. We therefore categorize $A \beta 40, A \beta 43$, and $\mathrm{A} \beta 46$ as one group and $\mathrm{A} \beta 42, \mathrm{~A} \beta 45$, and $\mathrm{A} \beta 48$ as the other. All of these indicate the presence of multiple cleavage sites between the $\gamma$ - and $\epsilon$-cleavage sites along the $\beta$ CTF molecule: the carboxyl sides of Thr-43, Val-46, and Ileu-45.

\section{Cleavage of the substrate at every three residues fits well with an $\boldsymbol{\alpha}$-helical model}

The transmembrane domain of $\beta$ CTF is postulated to adopt an $\alpha$-helix that needs 3.6 residues for one complete turn (Lichtenthaler et al., 1999b). According to this model, the cleavage sites for $\mathrm{A} \beta 49, \mathrm{~A} \beta 46$, $\mathrm{A} \beta 43$, and $\mathrm{A} \beta 40$ are aligned on the $\alpha$-helical surface of the $\beta$ CTF molecule, whereas those for $\mathrm{A} \beta 48, \mathrm{~A} \beta 45$, and $\mathrm{A} \beta 42$ are aligned on the other $\alpha$-helical surface (Fig. 9). We observed that the transient expression of $\mathrm{A} \beta 49$, a postulated major counterpart generated by $\epsilon$-cleavage, leads to predominant production of $\mathrm{A} \beta 40$, whereas the expression of $\mathrm{A} \beta 48$, a minor counterpart generated by $\epsilon$-cleavage, leads to preferential production of $\mathrm{A} \beta 42$ (Funamoto et al., 2004). Thus, it is possible that $\mathrm{A} \beta 40$ is produced from $\mathrm{A} \beta 49$ by cleaving at every three residues, whereas $A \beta 42$ is produced similarly from $\mathrm{A} \beta 48$. Alternatively, once the substrate, possibly a counterpart of AICD, is bound to $\gamma$-secretase, it is preferentially cleaved at the $\mathrm{A} \beta 40, \mathrm{~A} \beta 43$, or $\mathrm{A} \beta 46$ site, all aligning at one particular $\alpha$-helical surface of $\beta \mathrm{CTF}$, or at the $\mathrm{A} \beta 42$ or $\mathrm{A} \beta 45$ site, both aligning at the opposite surface (Fig. 9). However, there is insufficient evidence in our hands for coordinated cleavages for $\mathrm{A} \beta 42, \mathrm{~A} \beta 45$, and $\mathrm{A} \beta 48$. We did not observe similar differential accumulations of $A \beta 45$ and $\mathrm{A} \beta 48$ as for $\mathrm{A} \beta 43$ and $\mathrm{A} \beta 46$ (Fig. $8 B, C$ ), although differential susceptibility of $A \beta 42$ and $A \beta 45$ was observed: whereas $A \beta 42$ was already undetectable at $50 \mathrm{nM} D A P T, A \beta 45$ was still visible even at 250 nм DAPT (Fig. 8B).

Because three residues are insufficient for one complete $\alpha$-helical turn, the cleavage at every three residues cannot always occur and must be compensated by a cleavage at a four-residue distance. Presumably, this may explain our observation that the transient expression of $\mathrm{A} \beta 51$ leads to predominant production of $\mathrm{A} \beta 42$ and some $\mathrm{A} \beta 38$ (Funamoto et al., 2004). This possible conversion of $\mathrm{A} \beta 42$ to $\mathrm{A} \beta 38$ might be promoted by treatment with certain nonsteroidal anti-inflammatory drugs (Weggen et al., 2001).

Other substrates of $\gamma$-secretase, Notch-1 and CD44, undergo $\gamma$-like cleavage in addition to $\epsilon$-cleavage (thus called dual cleavage) and generate $A \beta$-like peptides (Okochi et al., 2002; Lammich et al., 2002). mNotch-1 is cleaved at the carboxyl side of Gly-1743 (site 3-cleavage) and further predominantly at the carboxyl side of Ala-1731 (site 4-cleavage). Similarly, CD44 is cleaved at the carboxyl side of Ile-287 and mainly at the carboxyl side of Ala-278 (Lammich et al., 2002). Thus, the distances

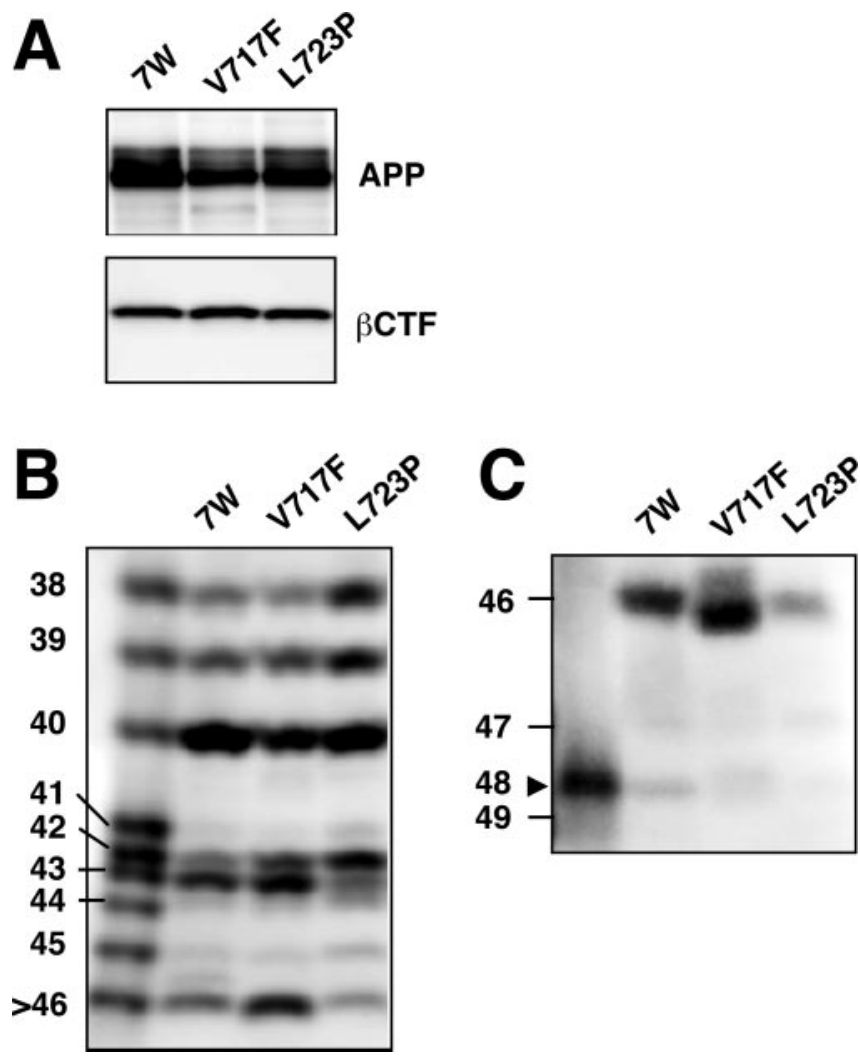

Figure 7. MtAPPs also altered the intracellular levels of longer $A \beta$ forms. $A$, The levels of APP and $\beta$ CTF were similar among 7WD10, V717F, and L723P mtAPP cells. The cell lysates were subjected to Western blotting with UT421 (top) or $82 E 1$ (bottom). $B, C$, The lysates of these cells were immunoprecipitated with BAN50, and the precipitated proteins were separated on gel I $(B)$ and gel II ( $C$ and subjected to Western blotting with 82E1. A slightly faster mobility of $A \beta 46$ in the V717F lane probably reflects V/F substitution at the position of $A \beta 46$. 

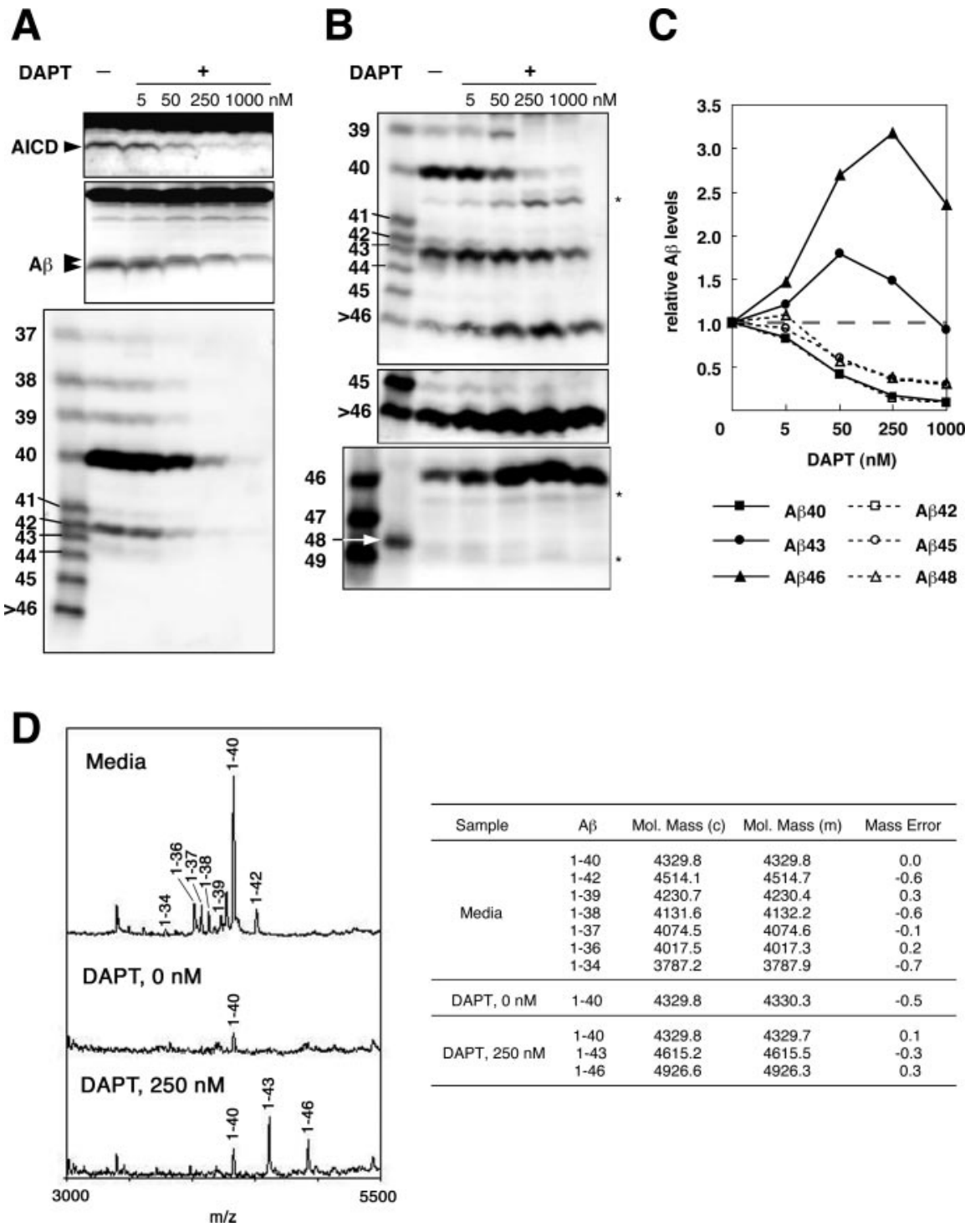

Figure 8. Differential effects of DAPT on the levels of longer $A \beta$ s. $A$, The cells that inducibly express $\beta C$ CTF were treated with the indicated concentrations of DAPT for $2 \mathrm{hr}$, and $\beta$ CTF was induced for $4 \mathrm{hr}$ in the presence of DAPT. Equal amounts of protein from the cell lysates were subjected to conventional Tris/Tricine gel electrophoresis, followed by Western blotting with UT421 to detect AICD (top) and with 82E1 to detect intracellular $A \beta$ (middle). The relatively broad band representing intracellular $A \beta$ apparently consists of two components that have slow and fast mobilities, as indicated by arrowheads. The fast-migrating $A \beta$ component declined at $5 \mathrm{~nm}$ DAPT and was not discernible at $50 \mathrm{~nm}$, whereas the slow-migrating $\mathrm{A} \beta$ component appeared to increase at $50 \mathrm{~nm}$ and was discernible even at $1000 \mathrm{~nm}$. The conditioned media were immunoprecipitated with BAN50, separated on gel I, and subjected to Western blotting with 82E1 (bottom). $B$, The lysates from those DAPT-treated cells were immunoprecipitated with BAN50, separated on gel I (top and middle) or gel II (bottom), and subjected to Western blotting with 82E1. The middle panel represents an overexposure of the top blot. A couple of bands indicated by asterisks are presumably C-terminally truncated $\beta C$ TFs. C, The amounts of intracellular $A \beta$ were quantified using LAS-1000plus luminescent image analyzer. The levels of each $A \beta$ species were normalized to those in the nontreated cells. The data shown are the means of the values from three (for $A \beta 40, A \beta 42, A \beta 43$, and $A \beta 45$ ) or two (for $A \beta 46$ and $A \beta 48$ ) independent experiments. $D$, Mass spectra of secreted $A \beta$ (top left) and intracellular $A \beta$ from cells treated without and with $250 \mathrm{~nm}$ DAPT (middle and bottom left, respectively) after immunoprecipitation using monoclonal antibodies 4G8 and 6E10. The calculated $(\mathrm{c})$ and observed $(\mathrm{m})$ masses are shown in the right panel. The suppression of secreted $A \beta s$ by DAPT was very similar to that by $L-685,458$. However, the effects on the intracellular $A \beta$ s were quite distinct between these two inhibitors (see Fig. 4).

between the site 3-cleavage and site 4-cleavage are just multiples of 3 , that is 12 and 9 residues for Notch-1 and CD44, respectively. This is consistent with our assumption for multiple cleavages on the one $\alpha$-helical surface at three-residue distance.

Based on the above observations, it is reasonable to assume that the catalytic site of $\gamma$-secretase for producing $\mathrm{A} \beta 40$ and that for producing A $\beta 42$ face the $\alpha$-helical surface of $\beta$ CTF molecule in topographically distinct manners. They would interact with the substrate $(\beta \mathrm{CTF})$ from opposite directions (Fig. $9 A$ ) and cleave it at multiple sites. It is possible that the $\gamma$-secretase complex made of dimeric PS (Schroeter et al., 2003) has both $\mathrm{A} \beta 40$ and $A \beta 42$-producing activities, and the substrate-bound side may determine the preference of the final product.

\section{Novel effects of DAPT}

We have shown here that longer $A \beta$ s and $\mathrm{A} \beta 40 / 42$ are produced at the same subcellular location (Fig. 5). However, the presence of longer $A \beta$ s itself does not necessarily mean that short $A \beta$ is processed from longer $A \beta$. This is because short $A \beta$ species $(\mathrm{A} \beta 40 / 42)$ could be produced by $\gamma$-cleavage in an independent manner. In this regard, inhibitors would be greatly helpful for the identification of intermediates for a particular product. If a certain inhibitor that prevents $A \beta 40 / 42$ generation causes an accumulation of longer $\mathrm{A} \beta \mathrm{s}$, these $\mathrm{A} \beta$ forms could be the intermediates for $A \beta 40 / 42$.

L-685,458, a transition-state analog, uniformly and nearly completely suppresses the intracellular levels of all the $\mathrm{A} \beta$ species and AICD in dose-dependent manners (Fig. 4). This strongly suggests that all of the $A \beta$ species are produced at the same catalytic site or at multiple sites that have the same catalytic properties. In contrast, DAPT builds up the longer $\mathrm{A} \beta \mathrm{s}$ in the cells, whereas it suppresses the secretion of several $A \beta s$, especially $A \beta 40$ and $\mathrm{A} \beta 42$, just as L-685,458 does (Fig. 8). A possible explanation is that $\mathrm{A} \beta 40, \mathrm{~A} \beta 43$, and $A \beta 46$ cleavage sites are competitive for the substrate of $\gamma$-secretase and that the $\mathrm{A} \beta 46, \mathrm{~A} \beta 43$, and $\mathrm{A} \beta 40$ cleavages are increasingly susceptible to DAPT in this order. Another explanation would be that $\mathrm{A} \beta 46$ is a precursor for $\mathrm{A} \beta 43, \mathrm{~A} \beta 43$ is a precursor for $A \beta 40$, and that the cleavages progress in a successive manner from the carboxyl side of the transmembrane domain of $\beta C T F$ to the middle of the membrane. Although the mode of action of DAPT remains unknown, these observations strongly suggest that DAPT affects mainly unidentified functions of the $\gamma$-secretase other than its catalytic function.

\section{Effects of FAD-associated $\mathrm{mtPS} 1 / 2$ and $\mathrm{mtAPP}$}

It has been unclear why a remarkable number of FAD mutations are scattered along the entire molecule of PS1, and yet all bring increased production of $\mathrm{A} \beta 42$. Here we have shown that many $\mathrm{mtPS} 1 / 2$ affect the intracellular levels of all longer $A \beta$ s in distinct manners. The apparent intracellular levels of longer $\mathrm{A} \beta$ s represent their steady-state levels in the cells. These steady-state levels 


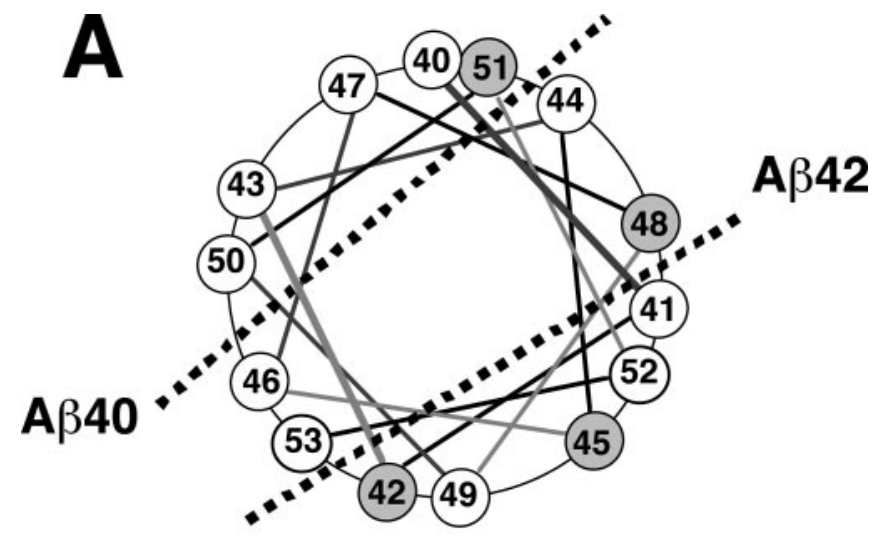

B

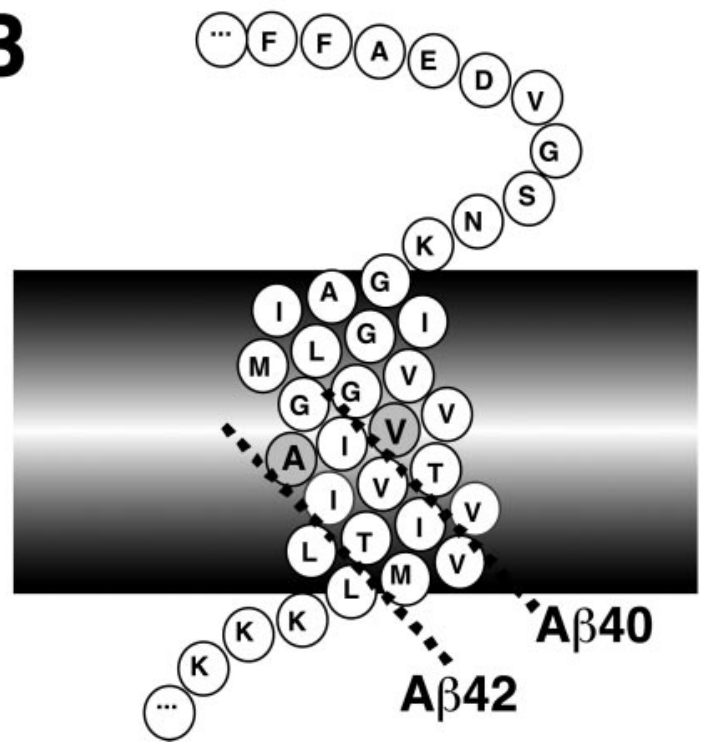

Figure 9. An $\alpha$-helical model showing processing of longer $A \beta$ s to $A \beta 40 / 42 . A, A$ view from the luminal side on the $\alpha$-helix wheel representing a carboxyl half of the transmembrane domain of APP. The number follows $A \beta$ numbering. The cleavage sites for generation of $A \beta 40$ and $A \beta 42$ (indicated by broken lines) are topographically in the opposite directions relative to the $\alpha$-helical surface of the transmembrane domain. The carboxyl sides of Val-46 and Thr- 43 are aligned with that of Val- 40 on the same side of the $\alpha$-helical surface. In contrast, the carboxyl sides of Thr- 48 and Ilu- 45 are aligned with that of Ala- 42 on the opposite side. $B$, A side view on the $\alpha$-helix of the transmembrane domain of APP. The cleavage sites for generation of $\mathrm{A} \beta 40$ and $\mathrm{A} \beta 42$ are distinctly aligned (indicated by broken lines) on the surface of the $\alpha$-helix of the transmembrane domain.

should be swiftly achieved by the balance between the efficiency of enzymatic catalysis at each cleavage site. We speculate that $\mathrm{mtPS} 1 / 2$ cause alterations in the cleavage efficiency at a multiple sites along the $\beta \mathrm{CTF}$ molecule, depending on the mutation loci along on the PS1/2 molecules. Thus, many FAD mutations could cause the same final effect, an increased level of $\mathrm{A} \beta 42$, through distinct alterations in the levels of longer $\mathrm{A} \beta \mathrm{s}$. If the FAD mutations of PS1/2 could also affect the substrate topological position relative to the catalytic site of $\gamma$-secretase, an even greater number of mutations would bring about the same consequence. The effects of FAD-associated mtAPP on the intracellular levels of longer $A \beta$ s are also diverse among the mutations, and this would be explained in a similar way.

\section{References}

Beher D, Wrigley JD, Owens AP, Shearman MS (2002) Generation of C-terminally truncated amyloid- $\beta$ peptides is dependent on $\gamma$-secretase activity. J Neurochem 82:563-575.
Citron M, Oltersdorf T, Haass C, McConlogue L, Hung AY, Seubert P, VigoPelfrey C, Lieberburg I, Selkoe DJ (1992) Mutation of the $\beta$-amyloid precursor protein in familial Alzheimer's disease increases $\beta$-protein production. Nature 360:672-674.

Clarke NJ, Tomlinson AJ, Ohyagi Y, Younkin S, Naylor S (1998) Detection and quantitation of cellularly derived amyloid $\beta$ peptides by immunoprecipitation-HPLC-MS. FEBS Lett 430:419-423.

De Strooper B, Saftig P, Craessaerts K, Vanderstichele H, Guhde G, Annaert W, Von Figura K, Van Leuven F (1998) Deficiency of presenilin-1 inhibits the normal cleavage of amyloid precursor protein. Nature 391:387-390.

Dovey HF, John V, Anderson JP, Chen LZ, de Saint Andrieu P, Fang LY, Freedman SB, Folmer B, Goldbach E, Holsztynska EJ, Hu KL, JohnsonWood KL, Kennedy SL, Kholodenko D, Knops JE, Latimer LH, Lee M, Liao Z, Lievergurg IM, Motter RN, et al. (2001) Functional $\gamma$-secretase inhibitors reduce $\beta$-amyloid peptide levels in brain. J Neurochem 76:173-181.

Funamoto S, Morishima-Kawashima M, Tanimura Y, Hirotani N, Saido TC, Ihara Y (2004) Truncated carboxyl-terminal fragments of $\beta$-amyloid precursor protein are processed to amyloid $\beta$-proteins 40 and 42 . Biochemistry 43:13532-13540.

Games D, Adams D, Alessandrini R, Barbour R, Berthelette P, Blackwell C, Carr T, Clemens J, Donaldson T, Gillespie F, Eckman C (1995) Alzheimer-type neuropathology in transgenic mice overexpressing V717F $\beta$-amyloid precursor protein. Nature 373:523-527.

Gu Y, Misonou H, Sato T, Dohmae N, Takio K, Ihara Y (2001) Distinct intramembrane cleavage of the $\beta$-amyloid precursor protein family resembling $\gamma$-secretase-like cleavage of Notch. J Biol Chem 276:35235-35238.

Haass C (2004) Take five-BACE and the $\gamma$-secretase quartet conduct Alzheimer's amyloid $\beta$-peptide generation. EMBO J 23:483-488.

Haass C, Hung AY, Selkoe DJ, Teplow DB (1994) Mutations associated with a locus for familial Alzheimer's disease result in alternative processing of amyloid $\beta$-protein precursor. J Biol Chem 269:17741-17748.

Hsiao K, Chapman P, Nilsen S, Eckman C, Harigaya Y, Younkin S, Yang F, Cole G (1996) Correlative memory deficits, $A \beta$ elevation, and amyloid plaques in transgenic mice. Science 274:99-102.

Iwatsubo T, Odaka A, Suzuki N, Mizusawa H, Nukina N, Ihara Y (1994) Visualization of $A \beta 42(43)$ and $A \beta 40$ in senile plaques with end-specific $\mathrm{A} \beta$ monoclonals: evidence that an initially deposited forms is $\mathrm{A} \beta 42(43)$. Neuron 13:45-53.

Jackson MR, Nilsson T, Peterson PA (1990) Identification of a consensus motif for retention of transmembrane proteins in the endoplasmic reticulum. EMBO J 9:3153-3162.

Kinebuchi M, Ide T, Lupin D, Tamatani T, Miyasaka M, Matsuura A, Nagai Y, Kikuchi K, Uede T (1991) A novel cell surface antigen involved in thymocyte and thymic epithelial cell adhesion. J Immunol 146:3721-3728.

Klafki HW, Wiltfang J, Staufenbiel M (1996) Electrophoretic separation of $\beta$ A4 peptides (1-40) and (1-42). Anal Biochem 237:24-29.

Koo EH, Squazzo SL (1994) Evidence that production and release of amyloid $\beta$-protein involves the endocytic pathway. J Biol Chem 269:17386-17389.

Lammich S, Okochi M, Takeda M, Kaether C, Capell A, Zimmer AK, Edbauer D, Walter J, Steiner H, Haass C (2002) Presenilin-dependent intramembrane proteolysis of CD44 leads to the liberation of its intracellular domain and the secretion of an $\mathrm{A} \beta$-like peptide. J Biol Chem 277:44754-44759.

Li YM, Xu M, Lai MT, Huang Q, Castro JL, DiMuzio-Mower J, Harrison T, Lellis C, Nadin A, Neduvelil JG, Register RB, Sardana MK, Shearman MS, Smith AL, Shi XP, Yin KC, Shafer JA, Gardell SJ (2000) Photoactivated $\gamma$-secretase inhibitors directed to the active site covalently label presenilin 1. Nature 405:689-694.

Lichtenthaler SF, Multhaup G, Masters CL, Beyreuther K (1999a) A novel substrate for analyzing Alzheimer's disease $\gamma$-secretase. FEBS Lett 453:288-292.

Lichtenthaler SF, Wang R, Grimm H, Uljon SN, Masters CL, Beyreuther K (1999b) Mechanism of the cleavage specificity of Alzheimer's disease $\gamma$-secretase identified by phenylalanine-scanning mutagenesis of the transmembrane domain of the amyloid precursor protein. Proc Natl Acad Sci USA 96:3053-3058.

Okochi M, Steiner H, Fukumori A, Tanii H, Tomita T, Tanaka T, Iwatsubo T, Kudo T, Takeda M, Haass C (2002) Presenilins mediate a dual intramembranous $\gamma$-secretase cleavage of Notch-1. EMBO J 21:5408-5416. 
Podlisny MB, Ostaszewski BL, Squazzo SL, Koo EH, Rydell RE, Teplow DB, Selkoe DJ (1995) Aggregation of secreted amyloid $\beta$-protein into sodium dodecyl sulfate-stable oligomers in cell culture. J Biol Chem 270:9564-9570.

Ponnambalam S, Rabouille C, Luzio JP, Nilsson T, Warren G (1994) The TGN38 glycoprotein contains two non-overlapping signals that mediate localization to the trans-Golgi network. J Cell Biol 125:253-268.

Qi Y, Morishima-Kawashima M, Sato T, Mitsumori R, Ihara Y (2003) Distinct mechanisms by mutant presenilin 1 and 2 leading to increased intracellular levels of amyloid $\beta$-protein 42 in Chinese hamster ovary cells. Biochemistry 42:1042-1052.

Sastre M, Steiner H, Fuchs K, Capell A, Multhaup G, Condron MM, Teplow DB, Haass C (2001) Presenilin-dependent $\gamma$-secretase processing of $\beta$-amyloid precursor protein at a site corresponding to the $\mathrm{S} 3$ cleavage of Notch. EMBO Rep 2:835-841.

Sato T, Dohmae N, Qi Y, Kakuda N, Misonou H, Mitsumori R, Maruyama H, Koo EH, Haass C, Takio K, Morishima-Kawashima M, Ishiura S, Ihara Y (2003) Potential link between amyloid $\beta$-protein 42 and C-terminal fragment $\gamma 49-99$ of $\beta$-amyloid precursor protein. J Biol Chem 278:24294-24301.

Schroeter EH, Ilagan MX, Brunkan AL, Hecimovic S, Li YM, Xu M, Lewis HD, Saxena MT, De Strooper B, Coonrod A, Tomita T, Iwatsubo T, Moore CL, Goate A, Wolfe MS, Shearman M, Kopan R (2003) A presenilin dimer at the core of the $\gamma$-secretase enzyme: insights from parallel analysis of Notch 1 and APP proteolysis. Proc Natl Acad Sci USA 100:13075-13080.

Seiffert D, Bradley JD, Rominger CM, Rominger DH, Yang F, Meredith Jr JE, Wang Q, Roach AH, Thompson LA, Spitz SM, Higaki JN, Prakash SR, Combs AP, Copeland RA, Arneric SP, Hartig PR, Robertson DW, Cordell B, Stern AM, Olson RE, Zaczek R (2000) Presenilin-1 and -2 are molecular targets for $\gamma$-secretase inhibitors. J Biol Chem 275:34086-34091.

Selkoe D, Kopan R (2003) Notch and presenilin: regulated intramembrane proteolysis links development and degeneration. Annu Rev Neurosci 26:565-597.

Selkoe DJ (2001) Alzheimer's disease: genes, proteins, and therapy. Physiol Rev 81:741-766.

Shearman MS, Beher D, Clarke EE, Lewis HD, Harrison T, Hunt P, Nadin A, Smith AL, Stevenson G, Castro JL (2000) L-685,458, an aspartyl protease transition state mimic, is a potent inhibitor of amyloid $\beta$-protein precursor $\gamma$-secretase activity. Biochemistry 39:8698-8704.

Sudoh S, Hua G, Kawamura Y, Maruyama K, Komano H, Yanagisawa K (2000) Intracellular site of $\gamma$-secretase cleavage for $A \beta 42$ generation in neuro 2a cells harbouring a presenilin 1 mutation. Eur J Biochem 267:2036-2045.

Suzuki N, Cheung TT, Cai XD, Odaka A, Otvos Jr L, Eckman C, Golde TE, Younkin SG (1994) An increased percentage of long amyloid $\beta$ protein secreted by familial amyloid $\beta$ protein precursor ( $\beta$ APP717) mutants. Science 264:1336-1340.

Takio K, Hasegawa M, Titani K, Ihara Y (1989) Identification of $\beta$ protein precursor in newborn rat brain. Biochem Biophys Res Commun 160:1296-1301.

Thinakaran G, Teplow DB, Siman R, Greenberg B, Sisodia SS (1996) Metabolism of the "Swedish" amyloid precursor protein variant in neuro2a (N2a) cells. Evidence that cleavage at the " $\beta$-secretase" site occurs in the golgi apparatus. J Biol Chem 271:9390-9397.

Tomita S, Kirino Y, Suzuki T (1998) A basic amino acid in the cytoplasmic domain of Alzheimer's $\beta$-amyloid precursor protein (APP) is essential for cleavage of APP at the $\alpha$-site. J Biol Chem 273:19304-19310.

Tomita T, Takikawa R, Koyama A, Morohashi Y, Takasugi N, Saido TC, Maruyama K, Iwatsubo T (1999) C terminus of presenilin is required for overproduction of amyloidogenic $\mathrm{A} \beta 42$ through stabilization and endoproteolysis of presenilin. J Neurosci 19:10627-10634.

Vassar R, Bennett BD, Babu-Khan S, Kahn S, Mendiaz EA, Denis P, Teplow DB, Ross S, Amarante P, Loeloff R, Luo Y, Fisher S, Fuller J, Edeson S, Lile J, Jarosinski MA, Biere AL, Curran E, Burgess T, Louis JC, et al. (1999) $\beta$-Secretase cleavage of Alzheimer's amyloid precursor protein by the transmembrane aspartic protease BACE. Science 286:735-741.

Wang R, Sweeney D, Gandy SE, Sisodia SS (1996) The profile of soluble amyloid $\beta$ protein in cultured cell media. Detection and quantification of amyloid $\beta$ protein and variants by immunoprecipitation-mass spectrometry. J Biol Chem 271:31894-31902.

Weggen S, Eriksen JL, Das P, Sagi SA, Wang R, Pietrzik CU, Findlay KA, Smith TE, Murphy MP, Bulter T, Kang DE, Marquez-Sterling N, Golde TE, Koo EH (2001) A subset of NSAIDs lower amyloidogenic A $\beta 42$ independently of cyclooxygenase activity. Nature 414:212-216.

Weidemann A, Eggert S, Reinhard FB, Vogel M, Paliga K, Baier G, Masters CL, Beyreuther K, Evin G (2002) A novel $\epsilon$-cleavage within the transmembrane domain of the Alzheimer amyloid precursor protein demonstrates homology with Notch processing. Biochemistry 41:2825-2835.

Wolfe MS, Xia W, Ostaszewski BL, Diehl TS, Kimberly WT, Selkoe DJ (1999) Two transmembrane aspartates in presenilin-1 required for presenilin endoproteolysis and $\gamma$-secretase activity. Nature 398:513-517.

Xia W, Zhang J, Kholodenko D, Citron M, Podlisny MB, Teplow DB, Haass C, Seubert P, Koo EH, Selkoe DJ (1997) Enhanced production and oligomerization of the 42 -residue amyloid $\beta$-protein by Chinese hamster ovary cells stably expressing mutant presenilins. J Biol Chem 272:7977-7982.

Yu C, Kim SH, Ikeuchi T, Xu H, Gasparini L, Wang R, Sisodia SS (2001) Characterization of a presenilin-mediated amyloid precursor protein carboxyl-terminal fragment $\gamma$. Evidence for distinct mechanisms involved in $\gamma$-secretase processing of the APP and Notch1 transmembrane domains. J Biol Chem 276:43756-43760. 